\title{
PENGARUH FISHING GAME TERHADAP KONSENTRASI ANAK TUNAGRAHITA DI SLB C ALPHA WARDAHANA SURABAYA
}

\author{
Ethyca Sari, Eklesia, ethyca.sari@yahoo.com ,STIKES Wiliam Booth Surabaya, \\ Prodi S1 Keperawatan ,Jl.Cimanuk no 20 Surabaya
}

\begin{abstract}
ABSTRAK
Gangguan kesehatan pada seorang anak salah satunya gangguan kesehatan yang mengalami hambatan dan perkembangan otak serta IQ yang dibawah rata-rata adalah anak Tunagrahita. Anak tunagrahita mengalami gangguan pada susunan saraf pusat dan mempunyai perhatian serta daya ingat yang lemah, konsentrasi yang mudah beralih, menyebabkan anak mengalami kesulitan menerima pelajaran atau mengikuti pembelajaran yang diberikan.Salah satunya tindakan yang dapat digunakan untuk anak tunagrahita yang mengalami gangguan konsentrasi adalah fishing game. Fishing game dapat meningkatkan konsentrasi anak Tunagrahita karena kegiatan bermain fishing game merupakan permainan yang mengunakan konsentrasi sehingga dalam memainkannya anak dilatih untuk berkonsentrasi agar dapat menyelesaikan permainan tersebut.Tujuan penelitian ini untuk mengetahui ada pengaruh fishing game terhadap konsentrasi anak tunagrahita di SLB C Alpha Wardahan Surabaya. penelitian ini mengunakan pra-eksperimen group pra-post test desaign. Variable independen yaitu fishing game dan variable dependen yaitu konsentrasi pada anak tunagrahita. Populasi penelitian adalah anak Tunagrahita di SLB C Alpha Wardahan Surabaya yang mengalami gangguan konsentrasi sebanyak 10 orang dengan jumlah sample 10 orang. Tehnik pengambilan sample dengan cara total sampling. Instrumen penelitian mengunakan lembar observasi. Analisa data mengunakan uji wilcoxon. Fishing game dengan konsentrasi cukup 7 (70\%) dan setelah dilakukan fishing game dengan konsentrasi sangat baik $4(40 \%)$ diperoleh nilai $\mathrm{p}=0,005$ sehingga terdapat pengaruh Fishing game terhadap konsentrsi anak tunagrahita di SLB C Alpha Wardahana Surabaya.Dilihat dari hasil penelitian ini maka fishing game dapat digunakan sebagai salah satu permainan untuk meningkat konsentrasi pada anak tunagrahita.
\end{abstract}

Kata kunci : Fishing Game, konsentrasi, Tunagrahita

\begin{abstract}
One of the health distraction of a student likes get an inhibilition and brain development also IQ of student is low is called Tunagrahita student. Tunagrahita student have disorder in nerve centre and have lee attention have disorder in nerve cemtre and less attention, memory, and concentration. It makes the student gets difficulties to follow teaching and learning process. One of actions taht can be used to increase the Tunagrahita Student's concentration by using Fishing game,because this game can force the student to think when they want force the student to think when they want to finish it. The objective of this research is to know the effect of Fishing game to the Tunagrahita students's concentration in SLB C Alpha Wardahana Surabaya. This research is using pra-experiment group prapost tes design. The independent variable is Fishing game and the depend variable is Tunagrahita Student's concentration. The population of the research is Tunagrahita student in SLB C Alpha Wardahana who have 10 students of conceration, total sample this research using total sampling. The instrument of the research is observation. The data analysis in this observation. The data analysis in this research is Uji Wilcoxon. Before ising fishing game the value of the student's comceration is 7 (70\%) and after using fishing game the student become $4(40 \%)$ the score $\mathrm{p}=0,005$. So, there is effect of fishing game to the Tunagrahita student's conceration in SLB C Alpha Wardahana Surabaya. According to the result of the researh, fishing game can be use ad one of the ways to increase the Tunagrahita student's conceration.
\end{abstract}

Keywords : fishing game, conceration, Tunagrahita 


\section{PENDAHULUAN}

Perkembangan anak merupakan sebuah proses yang indah dimata orang tua. Anak yang sehat secara fisik ataupun mental merupakan idaman orang tua, sehingga kecacatan fisik maupun mental diangap sebuah kelemahan tersendiri. Gangguan kesehatan pada seorang anak juga perlu mendapat perhatian, salah satunya gangguan kesehatan yang mengalami hambatan dan perkembangan otak serta IQ yang dibawah rata-rata adalah anak yang mengalami Tunagrahita. Tunagrahita adalah anak yang mempunyai kekurangan atau keterbatasan dari segi mental dan intelektual dibawah rata-rata normal, sehingga anak-anak tunagrahita akan mengalami kesulitan dalam tugas, akademik, komunikasi, dan memerlukan layanan pendidikan khusus (Sumarno, 2008). Anak tunagrahita mengalami gangguan pada susunan saraf pusat dan mempunyai kemampuan berfikir yang rendah, perhatian serta daya ingat yang lemah, konsentrasi yang mudah beralih, menyebabkan anak mengalami kesulitan menerima pelajaran atau mengikuti pembelajaran yang diberikan. Menurut Wijaya dan Ardhi (2016) menjelaskan bahwa anak tunagrahita adalah individu yang memiliki intelegensi yang signifikan berada dibawah rata-rata dan disertai dengan ketidakmampuan dalam adaptasi perilaku yang muncul dalam masa perkembangan dan kelainan yang menunjukkan hambatan dalam prilaku adaptif. Anak tunagrahita banyak mengalami gangguan dalam konsentrasi, walaupun tidak semua anak tunagrahita mengalaminya. Menurut Sandra (2010) tunagrahita terbagi menjadi 4 kategori yaitu ringan (debil), kategori sedang (Imbesil), kategori berat (Severe) dan kategori sangat berat (Profound). Tunagrahita ringan adalah tunagrahita yang dapat dilatih karena memiliki IQ 50-5 sampai 70. Berdasatkan test Binet kemampuan IQ-nya menunjukkan angka 68-52, sedangkan dengan tes Wechsler Intellgence Scale For Children (WISC), kemampuan IQ-nya 69-55 (Sandra, 2010). Anak tunagrahita sering mengalami gangguan perhatian yaitu mudah beralih perhatian dan kurang konsentrasi sehingga mengalami hambatan yang disebabkan oleh pengaruh kemampuan presepsinya, sehingga konsep pemahaman anak mengalami penyimpangan dari konsep yang ada (Sri 2013). Berdasarkan penelitian yang dilakukan oleh Umi Nadhiro (2017) menyatakan bahwa permainan Fishing game dapat meningkatkan konsentrasi. Fishing game merupakan permainan yang edukatif yang bersifat konstruktif dan menyenangkan, dimana fungsi utama fishing game secara umum adalah sebagai sarana untuk melatih anak dalam memahami instruksi yang diberikan oleh guru, tapi secara khusus fishing game dapat difungsikan untuk melatih konsentrasi anak. Berdasarkan hasil penelitian Umi Nadhiro melakukan fishing game dengan lama waktu 45 menit dilakukan 4 kali pertemuan dapat meningkatkan konsentrasi. Berdasarkan studi awal di Sekolah Luar Biasa (SLB) C Alpha Wardhana II Surabaya saat dilakukan wawancara dengan kepala sekolah, kepala sekolah mengatakan anak Tunagrahita di sekolah SLB C terdapat anak Tunagrahita yang mengalami masalah konsentrasi, salah satunya ketika belajar perhatian mudah beralih jika mendengar suatu hal sehingga tidak dapat bertahan duduk lama, menggangu teman melamun dan tidak konsentrasi terhadap pelajaran yang sedang berlangsung, akibatnya anak tidak berhasil mengikuti proses pembelajaran.

Menurut Kementrian Pendidikan Nasional Republik Indonesia pada tahun (2013) jumlah penduduk indonesia yang menyandang kelainan terdapat 345.815 orang adalah anak dengan Tunagrahita. Berdasarkan data dari Pusat Datadan Informasi (Pusdatin) Kesejahteraan Sosial, tunagrahita mengenai 1,5 kali lebih banyak pada laki-laki dibandingkan dengan perempuan (Judarwanto, 2009). Departemen Sosial RI Tahun 2013 jumlah penduduk di Indonesia yang menyandang kelainan retardasi mentaladalah 345.815 orang. Berdasarkan hasil study pendahuluan di di SLB C Alpha Wardhana II Surabaya terdapat 53 siswa yang terdiri dari 29 siswa tingkat Sekolah Menengah Pertama (SMP) dan 24 siswa tingkat Sekolah Dasar (SD) ,dari jumlah 53 siswa Tunagrahita tersebut yang mengalami gangguan konsentrasi 15 siswa yang berada di Sekolah Dasar.Upaya yang telah dilakukan oleh pihak sekolah adalah dengan memberikan permainan yang dapat meningkatkan konsentrasi seperti permainan balok dan ular tangga.

Penyebab terjadinya tunagrahita menurut Muttaqin (2008) faktor yang dapat menyebabkan terjadinya tunagrahita adalah faktor genetik, prenatal, perinternatal dan pascanatal, yaitu kelainan jumlah dan bentuk kromosom misalnya trisomi-21 atau dikenal dengan Mongolia atau Down Syndrome, gizi yang buruk, penyakit infeksi, terutama pada trimester pertama karena janin belum memiliki sistem kekebalan dan merupakan saat kritis bagi perkembangan otak, keracunan bahan kimia yang berbahaya, pada ibu berdampak pada janin, atau polutan lainnya yang terhirup oleh anak. Trauma kapitis atau tumor otak, kelainan tulang tengkorak, kelainan endokrin dan metabolik dan keracunan pada otak, hal ini mengakibatkan 
gangguan motorik dan mental, sehingga dapat mempengaruhi kemampuan anak Tunagrahita, salah satu kemampuan yang terganggu adalah konsentrasi belajar anak tunagrahita. Anak tunagrahita mempunyai kemampuan berpikir rendah, perhatian dan daya ingat yang lemah, konsentrasi yang mudah beralih serta sikap yang mudah bosan menyebabkan anak mengalami kesulitan dalam menerima pelajaran atau mengikuti pelajaran yang diberikan guru. Konsentrasi pada anak tunagrahita terjadi karena gangguan pada saraf pusat sehingga anak berpengaruh pada semua gerakan atau aktivitas yang dilakukan.Hal ini bisa berdampak pada fungsi kognitif, pada fungsi kognitif terjadi kelemahan diantaranya proses presepsi, ingatan, pengembangan ide dan penilaian penalaran, untuk menghindari anak yang kurang mampu berkonsentrasi, maka dapat dilakukan dengan aktivitas bermain.

Meningkatkan konsentrasi pada anak tunagrahita dapat dilakukan oleh perawat dengan caramelakukan beberapa macam permainan seperti permainan kolase, terapi permainan lotto, permainan puzzle, fishing game. Bermain adalah salah satu kegiatan yang penting bagi anak tunagrhita karena bermain merupakan kegiatan yang berulang-ulang demi kesenangan dan kepuasan. Beberapa permaianan tersebut mempunyai tujuan untuk meningkatkan konsentrasi pada anak, sedangkan fishing game ini dianggap lebih cocok dipergunakan pada anak tunagrahita karena alat yang dipergunakan mudah didapatkan, menyenangkan,dan mengasyikkan. Keistimewaan fishing game ini adalah dapat menarik minat belajar anak berkaitan langsun dengan kehidupan anak sehari-hari serta anak tidak mudah bosan dalam menerima materi pelajaran, sehingga fishing game ini akan dapat memacu anak lebih kreatif, aktif, dapat mengunggah rasa ingin tahu pada hal-hal yang bersifat nyata yang langsung dirasakan oleh anak. Berdasarkan penelitian penelitian Umi Nadhiroh (2017) fishing game merupakan suatu alat permainan edukatif (APE) yang bersifat konstruktif dan menyenangkan,dimana anak dapat mengambil ikan sesuai dengan instruksi yang telah diberikan. Tentunya dalam memainkannya diperlukan bimbingan untuk memberikan stimulus berupa kalimat perintah untuk memancing ikan.Maka dari itu penulis tertarik untuk melakukan penelitian "Pengaruh Fishing game Terhadap Konsentrasi anak Tunagrahita di SLB C Alpha Wardahana Surabaya."

\section{Rumusan Masalah}

Bagaimana mengidentifikasi konsentrasi anak tunagrahita sebelum dilakukan fishing game di SLB C Alpha Wardahana Surabaya?

Bagaimana mengidentifikasi konsentrasi anak tunagrahita setelah dilakukan fishing game di SLB C Alpha Wardahana Surabaya?

Bagaimana pengaruh fishing game terhadap konsentrasi anak tunagrhita di SLB C Alpha Wardahana Surabaya?

\section{Tujuan}

Tujuan Umum

Tujuan umum untuk penelitian ini adalah mengetahui pengaruh fishing game terhadap konsentrasi anak tunagrahita Surabaya.

\section{Tujuan Khusus}

Untuk mengidentifikasi bagaimana tingkat konsentrasi sebelum dilakukan fishing game di SLB C Alpha Wardahana Surabaya

Untuk mengidentifikasi bagaimana tingkat konsentrasi setelah dilakukan fishing game di SLB C Alpha Wardahana Surabaya

Untuk mengidentifikasi bagaimana pengaruh konsentrasi setelah dilakukan fishing game di SLB C Alpha Wardahana Surabaya

\section{Manfaat Penelitian}

Bagi peneliti

Hasil penelitian ini dapat menjadi acuan dalam proses berlajar dalam menerapakan ilmu yang telah diperoleh selama proses perkuliahan melalui pengumpulan data ilmiah dalam pembuatan proposal maupun skripsi yang bermanfaat.

Bagi Institusi

Hasil penelitian ini dapat menambah referensi bacaan dan bahan informasi yang bermanfaat atau mahawiswi STIKES Wiliam Booth Surabaya untuk penelitian selanjutnya.

Bagi Tempat Penelitian Sekolah SLB C Alpha Wardhana

Hasil penelitian ini diharapkan dapat menjadi refrensi dan penambahan wawasan mengenai bagaiamana peeningkatan konsentrasi dengan permaianan, sehingga berdampak baik pada proses pembelajaran dirumah maupun sekolah.

\section{BAHAN DAN METODE}

Desain penelitian yang digunakan dalam penelitian ini adalah pra-Eksperimen-group prapost test desaign (rencana pra-post dalam suatu kelompok). Tipe penelitian ini adalah menggungkapkan hubungan sebab akibat dengan cara melibatkan satu kelompok subjek. Kelompok 
subjek diobservasi sebelum melakukan intervensi, kemudian diobservasi lagi setelah intervensi (Narusalam, 2016).

Teknik Sampling menggunakan total sampling, yaitu adalah teknik pengambilan sampel dimana jumlah sampel sama dengan populasi (Sugiyono, 2007).Dari populasi sebanyak 15 orang semua dijadikan sempel penelitian.

\section{HASIL}

\section{Data Umum}

Distribusi responden berdasarkan jenis kelamin di SLB/C Alpha Wardahana Surabaya.

\begin{tabular}{cccc}
\hline No & $\begin{array}{c}\text { Jenis } \\
\text { kelamin }\end{array}$ & Jumlah & Persentase \\
\hline 1 & Laki-laki & 6 & 60 \\
2 & Perempuan & 4 & 40 \\
& Total & 10 & $100 \%$ \\
\hline
\end{tabular}

Berdasarkan data dari tabel diatas didapatkan responden sebanyak 6 siswa yaitu berjenis kelamin laki-laki $60 \%$

Distribusi responden berdasarkan usia siswa SLB/C Alpha Wardhana Surabaya

\begin{tabular}{cccc}
\hline No & Usia & Jumlah & Persentase \\
\hline \multirow{4}{*}{1} & $<12$ & & \\
2 & Tahun & 8 & $80 \%$ \\
& 13 Tahun & 2 & $20 \%$ \\
& Total & 10 & $100 \%$ \\
\hline & Berdasarkan & data dari & tabel diatas
\end{tabular}

responden berusia $<12$ tahun sebanyak 8 siswa $(80 \%)$

Distribusi responden berdasarkan urutan anak siswa SLB/C Alpha Wardahana Surabaya

\begin{tabular}{cccc}
\hline No & $\begin{array}{c}\text { Kategori } \\
\text { Tunagrahita }\end{array}$ & Jumlah & persentase \\
\hline 1 & Ringan & 10 & $100 \%$ \\
2 & Sedang & 0 & $0 \%$ \\
3 & Berat & 0 & $0 \%$ \\
& Total & 10 & $100 \%$
\end{tabular}

Berdasarkan data tabel diatas didapatkan responden sebagian besar kategori anak tunagrahita yaitu ringan 10 orang $(100 \%)$

Distribusi responden berdasakan pendidikan terahkir orang tua di SLB/C Alpha Wardahana Surabaya

\begin{tabular}{cccc}
\hline No & Pendidikan & Jumlah & Persentase \\
\hline 1 & SD & 2 & $20 \%$ \\
2 & SMP & 2 & $20 \%$ \\
3 & SMA & 4 & $40 \%$ \\
\hline
\end{tabular}

\begin{tabular}{cccc}
\hline 4 & SARJANA & 2 & 20 \\
& Total & 10 & $100 \%$
\end{tabular}

Berdasarkan data tabel diatas didapatkan sebagian besar pendidikan orang tua responden yaitu SMA sebanyak 4 orang $(40 \%)$

\section{Data Khusus}

Distribusi data hasil konsentrasi siswa SLB/C Alpha Wardahana Surabaya sebelum dilakukan permainan fishing

\begin{tabular}{llcc}
\hline No & $\begin{array}{l}\text { Tingkat } \\
\text { konsentrasi } \\
\text { siswa }\end{array}$ & Frekuensi & Persentase \\
\hline 1 & Sangat baik & - & - \\
2 & Baik & 3 & $30 \%$ \\
3 & Cukup & 7 & $70 \%$ \\
4 & Kurang & - & - \\
& Total & 10 & $100 \%$ \\
\hline
\end{tabular}

Berdasarkan tabel 5.1 didapatkan data hasil konsentrsi sebelum dilakukan fishing game bahwa sebagian besar responden memiliki tingkat konsentrasi cukup sebanyak 7 orang $(70 \%)$

Distribusi data hasil konsentrasi siswa SLB/C Alpha Wardahana Surabaya sesudah dilakuka Fishing game

\begin{tabular}{llcc}
\hline No & $\begin{array}{l}\text { Tingkat } \\
\text { konsentrasi siswa }\end{array}$ & Frekuensi & Persentase \\
\hline 1 & Sangat baik & 4 & $40 \%$ \\
2 & Baik & 6 & $60 \%$ \\
3 & Cukup & - & - \\
4 & Kurang & - & - \\
& Total & 10 & $100 \%$ \\
\hline
\end{tabular}

Berdasarkan tabel didapatkan hasil konsentrsi sesudah dilakukan fishing game bahwa sebagian besar bahwa responden memiliki tingkat konsentrasi Baik sebanyak 6 orang $(60 \%)$.

Distribusi hasil tingkat konsentrasi sebelum dan sesudah dilakukan Fishing game di SLB/C Alpha Wardahana

$\begin{array}{llclll}\text { No } & \text { Tingkat } & \text { Pre } & & \text { Post } & \\ & \text { konsentrasi } & \text { Fre } & \text { Presen } & \text { Frek } & \text { Presenta } \\ & \text { Siswa SLB/C } & \text { kue } & \begin{array}{l}\text { tase } \\ \text { nsi }\end{array} & \text { uensi } & \text { se } \\ & & & & (\%) \\ 1 & \text { Sangat baik } & - & - & 4 & 40 \% \\ 2 & \text { Baik } & 3 & 30 \% & 6 & 60 \% \\ 3 & \text { Cukup } & 7 & 70 \% & - & - \\ 4 & \text { Kurang } & - & - & - & - \\ & \text { Total } & 10 & 100 \% & 10 & 100 \%\end{array}$

Hasil Uji Statistik Wilcocon P:0,005 
Berdasarkan tabel dapat diketahu bahwa hasil penelitian di SLB/C Alpha Wardahana surabaya bahwa sebagian besar responden memiliki cukup konsentrasi sebelum dilakukan fishing game sebanyak 7 orang (70\%). Sedangkan setelah dilakukan fishing game mayoritas responden memiliki konsetrasi baik sebanyak 6 orang $(60 \%)$. Hasil analisa dari uji wilcoxon melalui program SPSS dengan derajat kemaknaan $\mathrm{p}<0,05$ dan didapatkan tingkat signifikan sebesar p: 0,005 sehingga HI diterima maka kesimpulannya ada pengaruh fishing game terhadap konsentrasi anak Tunagrahita di SLB/C Alpha Wardahan Surabaya.

\section{PEMBAHASAN}

Pada pembahasan ini akan diuraikan hasil penelitian mengenai pengaruh fishing game terhadap konsentrasi anak Tunagrahita di SLB/C Alpha Wardahana Surabaya.

\section{Tingkat Konsentrasi Anak Tunagrahita di SLB/C Alpha Wardahana Surabaya sebelum dilakukan fishing game.}

Berdasarkan data dapat dilihat bahwa sebelum dilakukan fishing game dari 10 responden terdapat 7 orang $(70 \%)$ yang memiliki tingkat konsentrasi cukup dan 3 orang (30\%) konsentrasi baik. Menurut Susanto (2006) konsentrasi adalah kemampuan seseorang untuk bisa mencurahkan perhatian dalam waktu yang relatif lama, anak yang dikatakan berkonsentrasi pada pelajaran jika dia memusatkan perhatian pada apa yang dipelajari, dengan berkonsentrasi anak tidak mudah mengalihkan perhatian pada apa yang dipelajari. Dalam proses pembelajaran, konsentrasi sangat berpengaruh terhadap hasil belajar, oleh karena itu setiap anak dalam mengikuti proses pembelajaran di sekolah diharapkan dapat berkonsentrasi dengan baik. Anak yang memiliki konsentrasi kurang baik tampak tidak bisa belajar lama, karena anak dengan gangguan konsentrasi tertentu tidak terganggu bila menghadapi hal yang disukai tetapi akan sangat bosan terhadap hal yang tidak disukai. Pada anak tunagrahita mengalami gangguan dalam berkonsetrasi, yang memiliki kesulitan untuk memusatkan perhatian dan tidak dapat fokus, seperti ketika belajar. Anak Tunagrahita termasuk anak yang kecerdasan terhambat, hampir sebagian anak tunagrahita mengalami keterbatasan intelektual berada dibawah rata-rata, pada anak tunagrahita memiliki Iq paling tinggi 70 (Moh Amin, 1995). Menurut peneliti anak tunagrahita yang mengalami gangguan konsentrasi kesulitan untuk memusatkan perhatian dan tidak dapat fokus, seperti ketika belajar perhatiannya mudah beralih jika mendengar sesuatu hal sehingga tidak dapat bertahan duduk lama, sering menengok ke kanan dan ke kiri, serta mengganggu temannya. Akibatnya anak tidak berhasil mengikuti proses pembelajaran dengan penuh perhatian. Berdasarkan hasil pengamatan pada siswa di SLB C tersebut diperoleh data bahwa, siswa tersebut terlihat lebih sering keluar dari tempat duduknya, melirik ke arah kanan dan kiri pada saat proses pembelajaran, sehingga dalam mengerjakan tugas menjadi lebih lama dan pemahaman terhadap informasi yang diperoleh menjadi tidak utuh. Hal ini menunjukkan konsentrasi anak berkurang

Berdasarkan data diatas didapatkan data kategori Tunagrahitra sebagian besar yaitu Tunagrahita ringan 10 orang $(100 \%)$. Menurut Somantri (2007) Anak Tunagrahita ringan adalah istilah yang digunakan untuk menyebut anak yang mempunyai kemampuan intelektual di bawah ratarata. karakteristik anak tunagrahita ringan di atas dapat ditegaskan bahwa karakteristik anak tunagrahita ringan antara lain kecerdasan anak antara 50-70, kemampuan bahasa rendah, tidak dapat berfikir secara abstrak, serta pada anak tunagrahita ringan mengalami gangguan dalam konsentrasi kerap kali mereka mengalami kegagalan dalam belajar. Hal ini menunjukkan bahwa terdapat kesesuaian antara fakta dan teori, berdasarkan hasil pengamatan peneliti di sekolah menunjukkan bahwa kemampuan berkonsentrasi anak belum sepenuhnya berkembang dengan baik dan rentang konsentrasi relatif singkat. Pada saat pembelajaran berlangsung, anak terlihat melamun, tidak memperhatikan gurunya dan memainkan jari tangan secara berulang- ulang. Hal ini menunjukan konsentrasi anak berkurang karena pada saat wawancara peneliti dengan guru di sekolah, memperoleh data atau informasi bahwa anak memiliki karakteristik konsenntrasi yang berkurang. Pada saat proses pembelajaran dikelas berlangsung saat guru memberikan perintah mengerjakan sesuatu, subjek terlihat tidak langsung mengerjakan perintah dari gurunya karena sibuk dengan hal- hal disekitar yang membuat anak tidak berkonsentrasi dan guru harus sering kali mengingatkan pada anak.

Berdasarkan data diatasdidapatkan data bahwa pendidikan terahkir orang tua dari responden hampir separuhnya adalah SMA sebanyak 4 orang $(40 \%)$. Susilowati (2007) pendidikan orang tua merupakan salah satu faktor penting dalam tumbuh kembang anak, karena dengan pendidikan yang 
baik maka orang tua dapat menerima segala info dari luar terutama tentang konsentrasi pembelajaran anak Tunagrahita. Makin tingginya tingkat pendidikan, akan makin mudah menyerap informasi dan inovasi baru bila dibandingkan dengan seseorang dengan tingkat pendidikan yang lebih rendah. Menurut penelitian Hardiyanto (2014) tentang pendidikan orang tua terhadap konsentrasi anak Tunagrahita didapatkan hasil bahwa terdapat pengaruh yang signifikan. Menurut peneliti pendidikan orang tua memegang peran yang sangat penting dalam tumbuh kembang anak Tunagrahita, karena orang tua adalah orang yang paling sering bersosialisasi dengan anak dan dapat membantu dalam tumbuh kembang anak.

\section{Tingkat Konsentrasi Anak Tunagrahita di SLB/C Alpha Wardahana Surabaya sesudah dilakukan fishing game}

Berdasarkan tabel distribusi pengukuran hasil tingkat konsentrasi sesudah melakukan fishing game ditemukan hasil data yang terbanyak adalah konsentrasi baik yaitu 6 orang $(60 \%)$. Teori fishing game yang disampaikan oleh (Umi Nadiroh 2015) permainan fishing merupakan suatu alat permainan edukatif (APE) yang bersifat konstruktif dan menyenangkan Sifat konstruktif yang berguna bagi pemakai permainanini adalah reproduktif ,dimana anak dapat mengambil ikan sesuai dengan instruksi. Metode ini menitik beratkan pada pembelajaran. Fishing game bisa dicobakan pada setiap anak yang membutuhkan optimalisasi kerja otak. Fungsi yang terdapat pada fishing game salah satunya melatih konsentrasi anak dan menambah daya ingat anak sehingga alat-alat dalam permainan sangat mendukung dalam proses belajar anak,untuk membuktikan bahwa fishing game mampu menambah tingkat konsentrasi belajar, peneliti bekerja sama dengan guru yang mengajar untuk memberikan evaluasi dimenit terahkir pelajaran untuk mengukur tingkat konsentrasi dan teryata ada peningkatan pada tingkat konsentrasi belajar. Teori tingkat konsentrasi yang disampaikan djmarah (2008) yang mengungkapkan bahwa konsentrasi merupakan pemusatan fungsi jiwa terhadap suatu objek seperti konsentrasi pikiran, perhatian dan sebagainya. Belajar dibutuhkan konsentrasi dalam bentuk perhatian yang terpusat pada suatu pelajaran. Maka dari itu konsentrasi merupakan salah satu aspek yang mendukung untuk mencapai prestasi yang baik dan apabila konsentrasi ini berkurang maka dalam mengikuti pembelajaran dikelas terganggu. Sesudah yang diberikan peneliti untuk evaluasi akhir diberikan setelah melakukan fishing game yang berupa lembar observasi konsentrasi. Sesudah dilakukan dengan mengukur tingkat konsentrasi menggunakan lembar observasi yang sama dilakukan saat sebelum tes. Fihsing game dilakukan selama $4 \mathrm{x}$ selama semingu pada saat pagi hari. Hasil yang didapatkan mengalami perubahan dari yang cukup konsentrasi menjadi konsentrasi baik. Menurut peneliti setelah diberikan tindakan fishing game sangat berpengaruh terhadap tingkat konsentrasi pada anak tunagrahita karena kegiatan bermain fishing game merupakan permainan yang mengunakan konsentrasi sehingga dalam memainkannya anak dilatih untuk berkonsentrasi agar dapat menyelesaikan permainan tersebut. Permainan Fishing game juga merupakan permainan yang tidak membosankan sehingga anak merasa betah dan senang karena model pancing dan ikan yang menarik dengan warna-warna cerah sehingga anak tertarik untuk memainkannya. Hal tersebut mengakibatkan anak menjadi betah bermain dan berusaha berkonsentrasi pada permainan fishing game sehingga tingkat konsentrasi anak tunagrahita meningkat serta anak memberi respon tingkat konsentrasi yang baik saat dilakukan observasi setelah diberikan permainan fishing game.

\section{Pengaruh fishing game terhadap konsentrasi anak Tunagrahita di SLB/C Alpha Wardahan Surabaya.}

Berdasarkan tabel Distribusi pengkuran tingkat konsentrasi sebelum dan sesudah diberikan tindakan Fishing game selama 4 hari didapatkan hasil bahwa terdapat pengaruh dari Fishing game terhadap tingkat konsentrasi. Peningkatan hasil tes pada responden dimana pada saat pre test hasil didapatkan hasil terbanyak pada tingkat konsentrasi cukup sebanyak 7 orang (70\%), tingkat konsentrasi baik 3 orang (30\%) namun pada sesudah tes tingkat konsentrasi baik sebanyak 6 orang $(60 \%)$, tingkat konsentrasi sangat baik sebanyak 4 orang (40\%). Hal ini menunjukan bahwa terjadi peningkatan terhadap tingkat konsentrasi belajar. Berdasarkan hasil Uji statistik Wilcoxon pengaruh Fishing game terhadap konsentrasi anak tunagrahita diketahui bahwa nilai $\mathrm{p}=0,005$ yaitu $\mathrm{p}<0,05$ dengan demikan $\mathrm{H}_{1}$ diterima yang berarti ada pengaruh fishing game terhadap konsentrasi anak tunagrahita di SLB/C Alpha Wardahana Surabaya. Hasil juga didukung oleh teori yang disampaikan oleh Umi Nadiroh (2015) permainan memancing merupakan suatu alat permainan edukatif (APE) yang dapat digunakan untuk mengembangkan konsentrasi pada saat pembelajaran serta memperoleh kesenangan atau kepuasan dari alat permainan tersebut. Konsentrasi 
dapat meningkat apabila permainan dilakukan dengan baik dan benar dapat bermanfaat bagi anak tunagrahita, sesuai dengan teori yang mengatakan bahwa Fishing game dapat meningkatkan konsentrasi anak tunagrahita dan juga didapatkan hasil setelah melakukan fishing game terjadi peningkatan yang signifikan dengan perubahan konsentrasi cukup dan baik menjadi sangat baik dan baik. Menurut peneliti Fishing game sangat efektif untuk digunakan sebelum pembelajatran dimulai dimana fishing game mampu meningkatkan kemampuan mereka dalam memokuskan pikiran.

\section{SIMPULAN}

Berdasarkan peneliti yang telah dilakukan maka dapat disimpulkan sebagai berikut :

Konsentrasi anak tunagrahita di SLB/C Alpha Wardahana Surabaya sebelum dilakukan permainan fishing game memiliki tingkat konsentrasi cukup 7 orang $(70 \%)$

Konsentrasi anak tunagrahita di SLB/C Alpha Wardahana Surabaya setelah dilakukan permainan Fishing game memiliki tingkat konsentrasi sangat baik 6 orang $(60 \%)$.

Ada pengaruh permainan Fishing game terhadap konsentrasi anak tunagrahita di SLB/C Alpha Wardahana Surabaya.

\section{SARAN}

\section{Bagi Tempat Penelitian}

Bagi SLB/C Alpha Wardahan Surabaya dengan adanya hasil penelitian ini diharapkan mampu meningkatkan konsentrasi anak Tunagarahita dengan menjadwalkan secara rutin fishing game pada sehingga berdampak baik pada proses pembelajaran dirumah maupun sekolah.

\section{Bagi institusi}

Diharapkan hasil penelitian ini dapat dijadikan referensi diperpustakaan STIKES Wiliambooth Surabaya dan sebagai salah satu acuan bagi $m$ ahasiswa untuk peladspanaan pengabdian masyarakat.

\section{DAFTAR PUSTAKA}

Adriana, Dian. 2011. Tumbuh Kembang dan Terapi Bermain pada Anak. Jakarta: Salemba Medika.

Ciptono\&Supriyanto S. 2010. Bina Anak Tunagrahita Karya Ilmiah disampaikan pada Penelitian Guru Bimbingan Khusus BP Diskus Prov Jawa Tengah, DinasPendidikan Provinsi Jawa Tengah, Tanggal 2-6 Agustus 2010.
D.syafrol.2013.peningkatan konsentrasi belajar anak autis dalam berhitung melalui keterampilan meronce.articel.php diakses tanggal 8 maret 2018

Delphie, Bandi 2006. Pembelajaran Anak Tunagrahita: Suatu Pengantar Dalam Pendidikan/Rad. Bandung: Refika Aditama.

Effendi, M. (2006). Pengantar Psiko pediagodik Anak Berkelainan. Jakarta: PT BumiAksara.

Fauzie, Mirza, M. (2014). Pengaruh Penyuluhan Terhadap Peningkatan Motivasi Dan Tindakan Dalam Mencuci Tangan Dan Membuang Sampah Pada Anak Penyandang Tunagrahita Di Sleman. Skripsi. JKL Poltekkes Kemenkes Yogyakarta.

Halimsyah. (2008). Pengantar Ilmu Keperawatan Anak. Jakarta : Salemba Medika.

Mumpuniarti. (2003). Ortodidaktik Tunagrahita. Yogyakarta: Universitas Negeri Yogyakarta

Nursalam.2005. Asuhan Keperawatan Bayi dan Anak. Jakarta: SalembaMedika.

Nursalam. 2011. Konsep dan Penerapan Metodologi Penelitian Ilmu Keperawatan. Jakarta: Salemba Medika.

Nuryanti, L. (2008). Psikologi Anak .Jakarta : PT Indeks

Nursalam. 2011. Konsep dan Penerapan Metodologi Penelitian Ilmu Keperawatan. Jakarta: Salemba Medika.

Nursalam.Konsep Penerapan Metodelogi Penelitian Ilmu Keperawatan: Pedoman Skripsi ,Tesis Dan Instrumen Penelitian Keperawatan EdisiI.Jakarta: Selemba Medika.

Harni.2016.Penerapan permainan memancing angka dalam meningkatkan pemahaman konsep bilangan pada anak kelompok TK A. http://digilib.iainkendari.ac.id/121/ diakses tanggal 8 febuari 2018.

Kurtz, A, L. (2008). Understanding Motor Skills in Children with Dyspraxia, Adho, Autism, And Other Learning Disabilities. London and Philadelpia: Jessica Kingsley

Rina.Ira. 2013. Jurnal psikologi dan terapan.Acedemia.edu diakses pada tanggal 1 febuari 2018

Salmiah, S. 2010. Retardasi Mental. Departemen Kedokteran Gigi Anak Fakultas Kedokteran Gigi: Universitas Sumatera Utara.

Sandra, M. 2010. Anak Cacat Bukan Kiamat : Metode Pembelajaran \& Terapi untuk Anak Berkebutuhan Khusus. KATAHATI: Yogyakarta

Supriyo.2008.studi kasus bimbingan konseling.semarang 
Slameto, Belajar dan Faktor-Faktor Yang Mempengaruhinya ; Rineka Cipta, Jakarta, 2010, hlm. 86

Sumarno, A. 2008. Karakteristik Anak Tunagrahita. Didapat dari URL: www. Elearning. unesa.ac.id. diakses tanggal 17Desember 2017.

Soetjiningsih. 2002. Tumbuh Kembang Anak. Jakarta: EGC

Tarmansyah. 2003.Rehabilitasi dan Terapi Untuk Individu yang Membutuhkan Layanan Khusus. Jakarta: Departemen Pendidikan Nasional Direktorat Jendral Pendidikan Tinggi Direktorat Pembinaan Penelitian dan Pengabdian KepadaMasyarakat.

Tursan Hakim, Mengatasi Gangguan Konsentrasi, Jakarta; Puspa Swara, 2008

Umi. Nadhiroh. Pengaruh permainan memancing terhadap konsentrasi anak autisdisidoarjo.jurnalmahasiswa.unesa.ac.id/ articlediakses pada hari rabu tanggal 7 febuari 2018. 